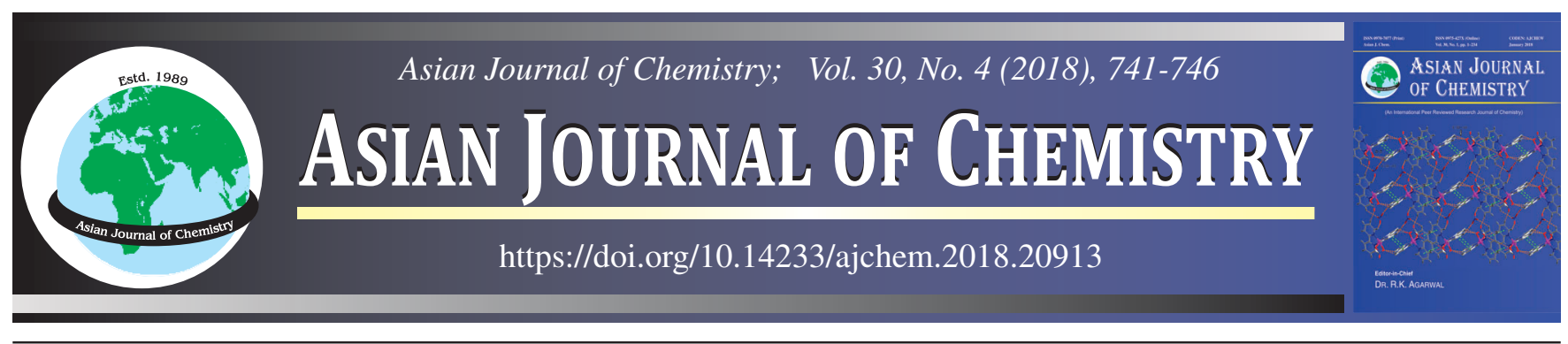

\title{
Molecular Docking Study of Novel Synthesized Pyrazole Derivatives and their Antibacterial Activity
}

\section{A.B. Senthieel Khumar, M.R. Ezhilarasi* and B. Prabha}

Department of Chemistry, Karpagam Academy of Higher Education, Coimbatore-641 021, India

*Corresponding author: E-mail: mrezhilarasi@gmail.com; ezhilarasi.au@gmail.com; m.r.ezhilarasi@gmail.com

The current novel series of 1-[5-(furan-2-yl)-4,5-dihydro-3-(4-morpholinophenyl)pyrazol-1-yl]ethanone are synthesized from the 3-(furan2-yl)-1-(4-morpholinophenyl)prop-2-ene-1-one by cyclization reaction. The 3-(furan-2-yl)-1-(4-morpholinophenyl)prop-2-ene-1-one chalcones are derived from the reaction of 4-morpholino acetophenone with substituted furfuraldehyde by common Claisen-Schmidt condensation reaction. The structures of the synthesized compounds skeleton are elucidated by IR, ${ }^{1} \mathrm{H}$ NMR and ${ }^{13} \mathrm{C}$ NMR. The antimicrobial susceptibility tests of synthesized compounds are screened against Staphylococcus aureus and Escherichia coli. From the three synthesized compounds the electron-withdrawing substitution $(\mathrm{Br})$ shows good effect against the Gram-positive bacteria and the electron donating substitution $\left(\mathrm{CH}_{3}\right)$ shows excellent inhibition zone against the Gram-negative bacteria at the concentration level $(10 \mu \mathrm{g} / \mathrm{mL})$. The molecular docking is an effective and component tool for in silico screening of bioactive compounds and Auto Dock 4.2.1 is used to find the binding interaction of synthesized compounds towards 3 selected bacterial proteins (2X5O, 3TYE, 3UDI).

Keywords: Claisen-Schmidt condensation, Pyrazole, Molecular docking, Antimicrobial activities.

(

\section{INTRODUCTION}

Among heterocycles, pyrazole derivatives are an important class of nitrogen containing five membered heterocyclic compounds that have more attention in the field of drug discovery and agricultural research [1-3]. Pyrazole have two adjacent $\mathrm{N}$-atom fused with three C-atom [4]. Pyrazoles and pyrazolones have special interest because they constitute an important class of natural and unnatural products [5]. They are rarely found in nature because due to difficulty in the formation of $\mathrm{N}-\mathrm{N}$ bond by the living organisms [6]. Significant effort has been put forth in developing approaches for pyrazole synthesis [7]. The heterocyclic compounds undergo the most common synthesis methods such as cyclocondensation [7] and Michal addition [8] when react with hydrazine hydrate to form a pyrazole moiety. The pyrazole moiety is a versatile lead molecule in the pharmaceutical development because of its wide range of biological activities such as antifungal $[9,10]$, antimicrobial [11-13], antiviral [14], anticancer [15], antitubercular [16,17], antitumor [18], antidepressant [19] and antibacterial [20].

The pyrazole moiety also used in the fluorescence, luminescence, herbicides [21], ligands [22], in the preparation of dyes [23] and as the corrosion inhibitors [8,24]. The successfully commercialized drugs contains pyrazole moiety are celexib, fipronil, sildenafil [7], pyrazofurin, lonazolac, rimonabant, ramifenazone and phenylbutazone [9]. The bis acetylated pyrazole [25] moiety also synthesized and it also have antimicrobial property [26].

Nowadays, infections are increased widely. The infections are caused by Gram-positive and Gram-negative pathogens [27]. For this reason, a number of drugs having antimicrobial property has to be produced. Due to this, in the present work the pyrazole derivatives are synthesized. The structure of the compounds are confirmed by IR, ${ }^{1} \mathrm{H}$ NMR and ${ }^{13} \mathrm{C}$ NMR spectral. The synthesized compounds subjected to antimicrobial screening test and try to compile the structure activity relationship (SAR) of pyrazole derivatives with different bacterial proteins such as 3TYE, 3UDI and 2X5O.

\section{EXPERIMENTAL}

Spectral devices: The MELT-TEMP apparatus is used to find the melting point of the synthesized compounds by using open capillary method. The IR spectra characterization is carried out by using SHIMADZU FT-IR spectrometer and the $\mathrm{KBr}$ pellet is used as a reference. The BRUKER $400 \mathrm{~Hz}$ and $100 \mathrm{~Hz}$ instrument is used for the ${ }^{1} \mathrm{H} \mathrm{NMR}$ and ${ }^{13} \mathrm{C}$ NMR spectral characterization of the synthesized compounds. During NMR characterization the TMS is used as a internal reference and $\mathrm{CDCl}_{3}$ as a solvent. 
Synthesis of 3-(furan-2-yl)-1-(4-morpholinophenyl)prop-2-ene-1-ones (1a-1c): $1 \mathrm{~mol}$ of 4-Morpholinoacetophenone and $1 \mathrm{~mol}$ of substituted furfuraldehyde are weighed. The 4-morpholino-acetophenone is taken in the $250 \mathrm{~mL}$ beaker containing $30 \mathrm{~mL}$ of $\mathrm{NaOH}$ mixed with ethanolic solution and stirred well. After that the weighed furfuraldehyde is added to it and mixed well. The mixture is placed in the ice-cold water bath and stirred well for $30 \mathrm{~min}$. The mixture is poured into a crushed ice and it is kept for a night at room temperature. Finally the solid chalcone is filtered, dried and recrystallized from ethanol. The purity of the chalcones is checked by TLC.

Synthesis of 1-[5-(furan-2-yl)-4,5-dihydro-3-(4-morpholinophenyl)pyrazol-1-yl]ethanone $(4 \mathrm{a}-4 \mathrm{c})$ : Various substituted chalcones are taken in the $250 \mathrm{~mL}$ round bottom flask which contains acetic acid as a solvent. The hydrazine hydrate $(1 \mathrm{~mol})$ is added to it and a pinch amount of sodium acetate is also added. This mixture is refluxed for 8-10 h. The completion of the reaction is monitored by TLC. Finally, the product precipitates out as a solid, filtered and dried. The structure of the synthesized compound is confirmed by IR, ${ }^{1} \mathrm{H}$ NMR and ${ }^{13} \mathrm{C}$ NMR spectral data. The elemental analysis is used to confirm the composition of atoms present in the synthesized compounds.

Lipinski's rule: This rule also known as Pfizer's rule of five, this is the rule to evaluate the drug likeness formulated by Christopher A. Lipinski based on oral administration of drugs [28]. This rule states that an orally active drug has no more than one violation of the following criteria, compound has (i) no more than $5 \mathrm{H}$-bond donors (the total no. of N-H and $\mathrm{O}-\mathrm{H}$ bonds), (ii) No more than $10 \mathrm{H}$-bond acceptors (all $\mathrm{N}$ or $\mathrm{O}$ atoms), (iii) The molecular mass is less than 500 (Daltons) (iv) An octanol-water partition coefficient $(\log \mathrm{P})$ not more than 5 , and (v) Not more than $120 \mathrm{~cm}^{3} / \mathrm{mol}$ of compounds molar refractivity.

Antimicrobial screening test: The inoculums and sterile swabs are constructed and sterilized. The synthesized compounds $\mathbf{4 a - 4} \mathbf{c}$ are subjected to antimicrobial screening against the Staphylococcus aureus (Gram-positive) pathogen and
Escherichia coli (Gram-negative) pathogen with the help of agar nutrient medium by disc-diffusion method. The maximum inhibition in minimum concentration of synthesized compounds is carried out by using micro-dilution method.

Molecular docking: Molecular docking studies have been carried out using the AutoDock Tools (ADT) version 1.5.6 and AutoDock version 4.2.5.1 docking program. The method of docking studies is followed by literature method [29].

\section{RESULTS AND DISCUSSION}

The new synthesized compound 1-[5-(furan-2-yl)-4,5dihydro-3-(4-morpholinophenyl)pyrazol-1-yl]ethanone (4a-4c) are synthesized from the reaction of (E)-3-(furan-2-yl)-1-(4morpholinophenyl) prop-2-en-1-one (3a-3c) with hydrazine hydrate in the presence of ethanol via Michal-addition mechanism. The compounds 3a-3c are synthesized by Claisen-Schmidt condensation reaction between furan-2-carbaldehyde and 2morpholino-1-phenylethanone. The pathway of the target compounds are shown in Fig. 1.

\section{Spectral data}

IR spectral values of synthesized compounds 4a-4c: The synthesized compounds $\mathbf{4 a - 4} \mathbf{c}$ show a characteristic band in $1645-1630 \mathrm{~cm}^{-1}$ region due to the presence of amide $\mathrm{C}=\mathrm{O}$ stretching frequencies. The stretching frequency around 3000 $\mathrm{cm}^{-1}$ shows the peak of the aliphatic $\mathrm{CH}$ stretching. The aromatic $\mathrm{CH}$ group shows the stretching frequency from the range of 3000-2950 $\mathrm{cm}^{-1}$. The absorption band of the group C-N shows band around at $1110 \mathrm{~cm}^{-1}$ and the group $\mathrm{C}=\mathrm{N}$ stretching presence in the range of $1450 \mathrm{~cm}^{-1}$. The remaining stretching frequencies are $833.25,821.68,767.67,754.17$ and 744.52 $\mathrm{cm}^{-1}$ due to presence of aromatic ring moiety.

${ }^{1} \mathrm{H}$ and ${ }^{13} \mathrm{C}$ NMR spectral values of synthesized compounds 4a-4c: The ${ }^{1} \mathrm{H}$ NMR of the synthesized compound $\mathbf{4 a}$ shows the acetyl methyl protons present in the pyrazoline moiety gives the singlet signal at $2.237 \mathrm{ppm}$. The protons in the $-\mathrm{N}\left(\mathrm{CH}_{2}\right)_{2}$ group of morpholine moiety shows a doublet at $3.15 \mathrm{ppm}$ and the coupling constant value, $J=4.4 \mathrm{~Hz}$ and the protons of

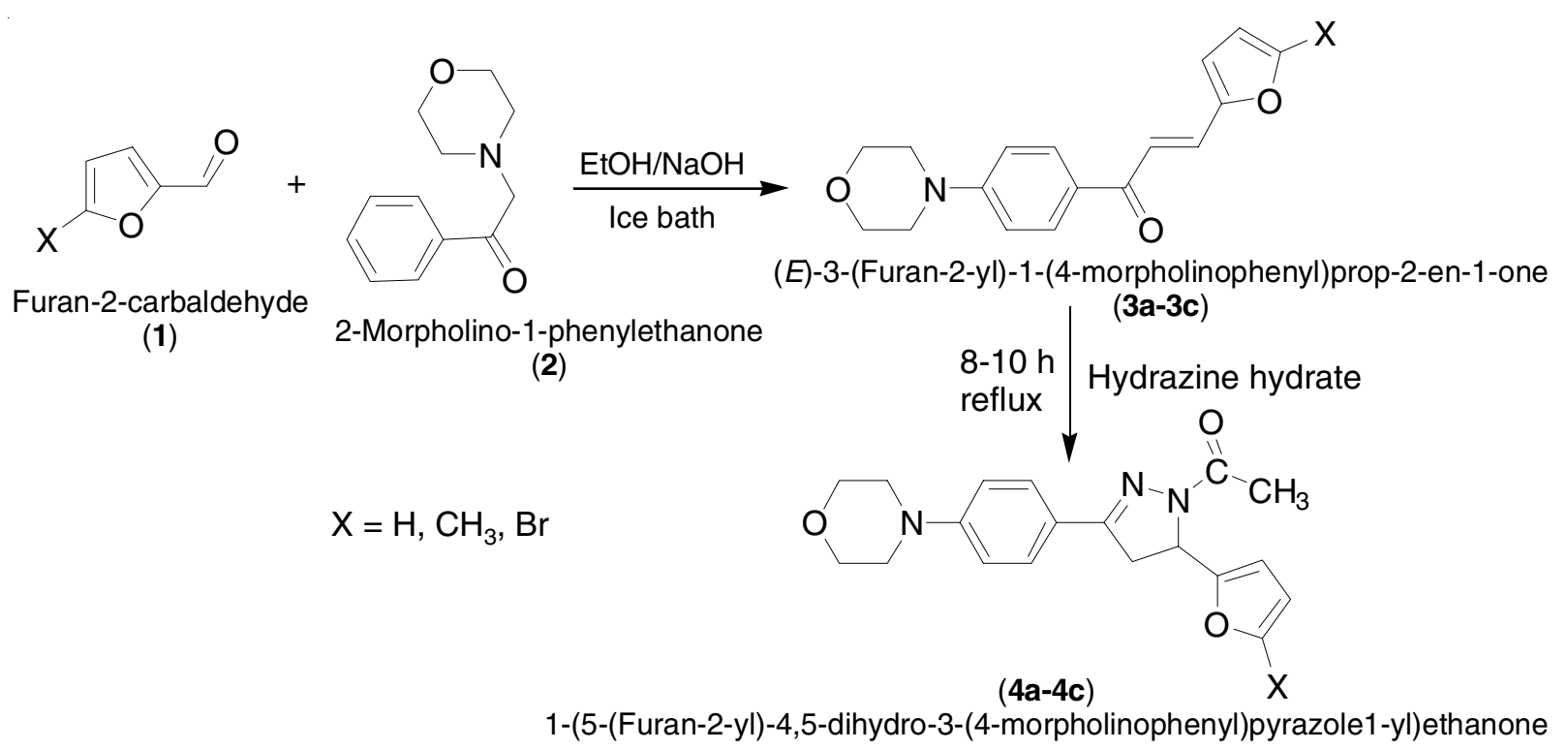

Fig. 1. Reaction scheme of the synthesized compounds $\mathbf{4 a - 4 c}$ 
$-\mathrm{O}\left(\mathrm{CH}_{2}\right)_{2}$ in the same moiety which also gives the doublet at 3.73 with the value of $J=4.4 \mathrm{~Hz}$. The methylene protons $(\mathrm{H}-4 \mathrm{a}$ and $\mathrm{H}-4 \mathrm{e}$ ) of the pyrazoline moiety appeared as two doublet of doublet due to multiple coupling by involving both germinal and vicinal protons. The signals of $\mathrm{H}-4 \mathrm{a}$ and $\mathrm{H}-4 \mathrm{e}$ are observed at $3.23 \mathrm{ppm}$ and $3.65 \mathrm{ppm}$. The doublet of doublet of $\mathrm{H}-4 \mathrm{a}$ of pyrazoline moiety is assigned at $3.23 \mathrm{ppm}$ with the coupling constant values $J_{4 a, 5 a}=19.6 \mathrm{~Hz}$ and $J_{4 a, 4 \mathrm{e}}=4.4 \mathrm{~Hz}$. In the same way, the doublet of doublet is assigned at $3.65 \mathrm{ppm}\left(J_{4 \mathrm{e}, 4 \mathrm{a}}=\right.$ $11.6 \mathrm{~Hz}$ and $J_{4 \mathrm{e}, 5 \mathrm{a}}=18 \mathrm{~Hz}$ ) for an $\mathrm{H}-4 \mathrm{e}$ protons. The another one doublet of doublet is observed in the range of $5.58 \mathrm{ppm}$ $\left(J_{5 \mathrm{a}, 4 \mathrm{a}}=4 \mathrm{~Hz}\right.$ and $\left.J_{5 \mathrm{a}, 4 \mathrm{e}}=11.6 \mathrm{~Hz}\right)$ is due to the presence of the methine proton (H-5) of pyrazoline moiety and vicinal coupling with two magnetically non-equivalent protons of methylene group ( $\mathrm{H}-4 \mathrm{a}$ and $\mathrm{H}-4 \mathrm{e})$. Further, the $\mathrm{H}-3$ proton of furan moiety gives a signal at $6.38 \mathrm{ppm}$ and $\mathrm{H}-4$ proton of the same ring shows doublet signal at $6.28 \mathrm{ppm}$ with the $J$ value is equal to $2.4 \mathrm{~Hz}$. The $\mathrm{H}-2$ and $\mathrm{H}-6$ protons of phenyl ring gives the signal at $7.64(\mathrm{~J}=8.4 \mathrm{~Hz})$ and the $\mathrm{H}-3$ and $\mathrm{H}-5$ of phenyl ring shows signal at $7.53 \mathrm{ppm}$.

${ }^{13} \mathrm{C}$ NMR of the synthesized compound $4 \mathrm{a},{ }^{13} \mathrm{C}$ resonance at $47.39 \mathrm{ppm}$ is assigned to the $\mathrm{C}-5$ of pyrazole moiety and the signals at $38.35 \mathrm{ppm}$ and $154.34 \mathrm{ppm}$ are assigned for the $\mathrm{C}-4$ and $\mathrm{C}-3$ carbons of the pyrazole ring. The ${ }^{13} \mathrm{C}$ resonance is observed at $21.64 \mathrm{ppm}$ is due to the presence of acetyl methyl group which is attached in the pyrazole moiety and the signal at $167.11 \mathrm{ppm}$ is assigned for acetyl $\mathrm{C}=\mathrm{O}$ group is also attached in the same ring. The signal at $52.67 \mathrm{ppm}$ is assigned for the $\mathrm{N}\left(\mathrm{CH}_{2}\right)_{2}$ group of morpholine moiety and in the same ring the $\mathrm{O}\left(\mathrm{CH}_{2}\right)_{2}$ group shows a signal at $65.87 \mathrm{ppm}$. In furan ring, the signals appeared in the positions $152.25 \mathrm{ppm}, 106.76 \mathrm{ppm}$, $110.13 \mathrm{ppm}$ and $142.13 \mathrm{ppm}$ positions which is assigned to the C-2, C-3, C-4 and C-5 carbons respectively. The C-3 and C-5 position have a signal at the $114.16 \mathrm{ppm}$ and the C-2 \& C-6 carbons signal appeared at $127.75 \mathrm{ppm}$. The $\mathrm{C}-1$ carbon of phenyl ring shows a signal at $120.96 \mathrm{ppm}$ and the $\mathrm{C}-4$ carbon of the same ring shows signal at the range $152.92 \mathrm{ppm}$. The ${ }^{1} \mathrm{H}$ NMR and ${ }^{13} \mathrm{C}$ NMR results of compounds are shown in Tables 1 and 2.

Lipinski rule of compounds 4a-4c: The synthesized compounds $\mathbf{4 a - 4} \mathbf{c}$ obey the Lipinski rule of five. Thus, all the compounds have drug likeness property. The values are shown in Table- 3 .

Antibacterial activity: The synthesized compounds $4 a-4 c$ show the highest activity against Gram-positive and Gramnegative bacterial strains. According to the inhibition result, the $\mathrm{CH}_{3}$ (e- donating) substitution has wide spectrum against Gram-negative bacteria E. coli and the $\mathrm{Br}$ ( $\mathrm{e}^{-}$withdrawing) substitution has excellent inhibition against Gram-positive bacteria $S$. aureus. All the synthesized compounds show the best inhibition value at $10 \mu \mathrm{g} / \mathrm{mL}$. The inhibition values of the synthesized compounds are given in Table-4.

TABLE-1

${ }^{1}$ H NMR CHEMICAL SHIFT VALUES OF THE SYNTHESIZED COMPOUND 4a-4c

\begin{tabular}{|c|c|c|c|c|c|c|c|c|c|c|}
\hline \multirow[b]{2}{*}{ Compd. } & \multicolumn{10}{|c|}{ Chemical Shifts ( $\delta$ ppm) } \\
\hline & $\begin{array}{c}\text { Acetyl } \\
\mathrm{CH}_{3}\end{array}$ & $\begin{array}{c}\mathrm{N}\left(\mathrm{CH}_{2}\right)_{2} \text { of } \\
\text { morpholine } \\
\text { moiety }\end{array}$ & $\begin{array}{c}\mathrm{O}\left(\mathrm{CH}_{2}\right)_{2} \text { of } \\
\text { morpholine } \\
\text { moiety }\end{array}$ & $\begin{array}{l}\mathrm{H}-4 \mathrm{a} \text { of } \\
\text { pyrazole } \\
\text { ring }\end{array}$ & $\begin{array}{l}\mathrm{H}-4 \mathrm{e} \text { of } \\
\text { pyrazole } \\
\text { ring }\end{array}$ & $\begin{array}{c}\text { H-5a of } \\
\text { pyrazole } \\
\text { ring }\end{array}$ & $\begin{array}{l}\mathrm{H}-3 \text { of } \\
\text { furan } \\
\text { moiety }\end{array}$ & $\begin{array}{l}\mathrm{H}-4 \text { of } \\
\text { furan } \\
\text { moiety }\end{array}$ & $\begin{array}{c}\mathrm{H}-2 \& \mathrm{H}- \\
6 \text { proton } \\
\text { of phenyl } \\
\text { ring }\end{array}$ & $\begin{array}{l}\mathrm{H}-3 \text { \& H- } \\
5 \text { proton } \\
\text { of phenyl } \\
\text { ring }\end{array}$ \\
\hline $4 \mathbf{a}(\mathrm{H})$ & 2.237 & $\begin{array}{l}3.15(\mathrm{~d}) \mathrm{J} \\
=4.4 \mathrm{~Hz}\end{array}$ & $\begin{array}{l}3.73(\mathrm{~d}) \mathrm{J} \\
=4.4 \mathrm{~Hz}\end{array}$ & $\begin{array}{c}3.23(\mathrm{dd}) \\
\left(J_{4 \mathrm{a} .4 \mathrm{e}}=\right. \\
4.4 \mathrm{~Hz} \& \\
J_{4 \mathrm{a}, 5 \mathrm{e}}= \\
19.6 \mathrm{~Hz})\end{array}$ & $\begin{array}{c}3.65(\mathrm{dd}) \\
\left(J_{4 \mathrm{e} .4 \mathrm{a}}=11.6\right. \\
\mathrm{Hz} \& J_{4 \mathrm{e} .5 \mathrm{a}} \\
=18 \mathrm{~Hz})\end{array}$ & $\begin{array}{c}5.58(\mathrm{dd}) \\
\left(J_{5 \mathrm{a} .4 \mathrm{a}}=4\right. \\
\mathrm{Hz} \& J_{5 \mathrm{a}, 4 \mathrm{e}} \\
=11.6 \\
\mathrm{~Hz})\end{array}$ & $6.38(d)$ & $\begin{array}{l}6.28(\mathrm{~d}) \mathrm{J} \\
=2.4 \mathrm{~Hz}\end{array}$ & $\begin{array}{l}7.64(\mathrm{~d}) \mathrm{J} \\
=8.4 \mathrm{~Hz}\end{array}$ & $7.53(d)$ \\
\hline $\begin{array}{c}\mathbf{4 b} \\
\left(\mathrm{CH}_{3}\right)\end{array}$ & $\begin{array}{c}2.23 \\
\& \mathrm{CH}_{3} \text { in } \\
\text { furan } \\
\text { moiety = } \\
2.18 \mathrm{~Hz}\end{array}$ & $3.13(\mathrm{~d})$ & $3.74(d)$ & $\begin{array}{c}3.26(\mathrm{dd}) \\
\left(J_{4 \mathrm{a} .4 \mathrm{e}}=\right. \\
4.2 \mathrm{~Hz} \\
\& J_{4 \mathrm{a} .5 \mathrm{a}}= \\
18 \mathrm{~Hz})\end{array}$ & $\begin{array}{c}3.63(\mathrm{dd}) \\
\left(J_{4 \mathrm{e} .4 \mathrm{a}}=11.6\right. \\
\mathrm{Hz} \& J_{4 \mathrm{e} .5 \mathrm{a}}= \\
17.6 \mathrm{~Hz})\end{array}$ & $\begin{array}{c}5.51(\mathrm{dd}) \\
\left(J_{5 \mathrm{a} .4 \mathrm{a}}=\right. \\
4.4 \mathrm{~Hz} \& \\
J_{5 \mathrm{a} .4 \mathrm{e}}= \\
11.6 \mathrm{~Hz}) \\
\end{array}$ & $6.28(d)$ & $\begin{array}{l}6.13(\mathrm{~d}) \mathrm{J} \\
=2.4 \mathrm{~Hz}\end{array}$ & $\begin{array}{l}7.64(\mathrm{~d}) \mathrm{J} \\
=8.6 \mathrm{~Hz}\end{array}$ & $\begin{array}{l}6.99(\mathrm{~d}) \mathrm{J} \\
=8.8 \mathrm{~Hz}\end{array}$ \\
\hline $4 c(B r)$ & 2.24 & $\begin{array}{c}3.21(\mathrm{~d}) \mathrm{J} \\
=4 \mathrm{~Hz}\end{array}$ & $\begin{array}{l}3.73(\mathrm{~d}) \mathrm{J} \\
=4.4 \mathrm{~Hz}\end{array}$ & $\begin{array}{c}3.30(\mathrm{dd}) \\
\left(J_{4 \mathrm{a} .4 \mathrm{e}}=\right. \\
4.8 \mathrm{~Hz} \& \\
J_{4 \mathrm{a}, 5 \mathrm{a}}=18 \\
\mathrm{~Hz})\end{array}$ & $\begin{array}{c}3.68(\mathrm{dd}) \\
\left(J_{4 \mathrm{e} .4 \mathrm{a}}=9.4\right. \\
\mathrm{Hz} \& J_{4 \mathrm{e} .5 \mathrm{a}} \\
=18.4 \mathrm{~Hz})\end{array}$ & $\begin{array}{c}5.55(\mathrm{dd}) \\
\left(J_{5 \mathrm{a} .4 \mathrm{a}}=\right. \\
4.4 \mathrm{~Hz} \& \\
J_{5 \mathrm{a}, 4 \mathrm{e}}= \\
11.8 \mathrm{~Hz})\end{array}$ & $\begin{array}{c}6.47(\mathrm{~d}) \\
J=2.8 \\
\mathrm{~Hz}\end{array}$ & $\begin{array}{l}6.36(\mathrm{~d}) \mathrm{J} \\
=3.2 \mathrm{~Hz}\end{array}$ & $\begin{array}{l}7.64(\mathrm{~d}) \mathrm{J} \\
=8.4 \mathrm{~Hz}\end{array}$ & $\begin{array}{l}6.99(\mathrm{~d}) \mathrm{J} \\
=8.8 \mathrm{~Hz}\end{array}$ \\
\hline
\end{tabular}

TABLE-2

${ }^{13}$ C NMR CHEMICAL SHIFT VALUES OF SYNTHESIZED COMPOUND 4a-4c

\begin{tabular}{|c|c|c|c|c|c|c|c|c|c|}
\hline \multirow{3}{*}{ Compound } & \multicolumn{9}{|c|}{ Chemical shifts ( $\delta$ values in ppm) } \\
\hline & \multirow{2}{*}{ Acetyl $\mathrm{CH}_{3}$} & \multirow{2}{*}{\multicolumn{2}{|c|}{ Acetyl $\mathrm{C}=\mathrm{O}$}} & \multicolumn{3}{|c|}{ Pyrazole moiety } & \multicolumn{3}{|c|}{ Morpholine moiety } \\
\hline & & & & $\mathrm{C}-3$ & C-4 & C-5 & \multicolumn{2}{|c|}{$\mathrm{N}\left(\mathrm{CH}_{2}\right)_{2}$} & $\mathrm{O}\left(\mathrm{CH}_{2}\right)_{2}$ \\
\hline $\mathbf{4 a}(\mathrm{H})$ & 21.64 & & & 154.34 & 38.35 & 47.39 & & & 65.87 \\
\hline $4 \mathbf{b}\left(\mathrm{CH}_{3}\right)$ & 21.69 & & & 154.25 & 38.33 & 47.40 & & & 65.88 \\
\hline \multirow[t]{3}{*}{$\mathbf{4 c}(\mathrm{Br})$} & 21.64 & & & 155.26 & 38.32 & 47.37 & & & 65.87 \\
\hline & \multicolumn{5}{|c|}{ Furan moiety } & \multicolumn{4}{|c|}{ Phenyl ring } \\
\hline & $\mathrm{C}-2$ & $\mathrm{C}-3$ & $\mathrm{C}-4$ & $\mathrm{C}-5$ & $\mathrm{CH}_{3}$ & $\mathrm{C}-3$ \& C-5 & $\mathrm{C}-2 \& \mathrm{C}-6$ & $\mathrm{C}-1$ & $\mathrm{C}-4$ \\
\hline $\mathbf{4 a}(\mathrm{H})$ & 152.25 & 106.76 & 110.13 & 142.13 & - & 114.16 & 127.75 & 120.96 & 152.92 \\
\hline $4 \mathbf{b}\left(\mathrm{CH}_{3}\right)$ & 151.24 & 106.40 & 110.44 & 150.77 & 66.03 & 114.17 & 127.75 & 121.02 & 152.24 \\
\hline $\mathbf{4 c}(\mathrm{Br})$ & 152.28 & 109.8 & 112.42 & 114.15 & - & 114.15 & 127.82 & 120.79 & 152.28 \\
\hline
\end{tabular}




\begin{tabular}{|c|c|c|c|c|c|}
\hline \multicolumn{6}{|c|}{$\begin{array}{c}\text { TABLE-3 } \\
\text { LIPINSKI RULE VALES OF COMPOUNDS } \mathbf{4 a - 4 c}\end{array}$} \\
\hline \multirow[b]{2}{*}{ Compound } & \multicolumn{5}{|c|}{ Lipinski rule of five } \\
\hline & $\begin{array}{l}\text { H-bond donors } \\
(\text { not }>5)\end{array}$ & $\begin{array}{c}\text { H-bond acceptors } \\
(\text { not }>10)\end{array}$ & $\begin{array}{c}\text { Molecular mass (not } \\
\text { greater than } 500 \text { daltons) }\end{array}$ & $\begin{array}{l}\log \mathrm{P}(\text { no greater } \\
\text { than 5) }\end{array}$ & $\begin{array}{c}\text { Molar refractivity } \\
\text { (between } 30-120 \text { ) } \mathrm{cm}^{3} / \mathrm{mol}\end{array}$ \\
\hline $4 \mathbf{a}$ & $<5$ & $<10$ & 339.16 & 1.35 & 95.78 \\
\hline $4 b$ & $<5$ & $<10$ & 353.17 & 1.68 & 100.73 \\
\hline $4 c$ & $<5$ & $<10$ & 417.07 & 2.06 & 103.7 \\
\hline
\end{tabular}

Docking result: Since the molecular mechanism of the antibacterial activity of synthesized pyrazoles $(\mathbf{4 a - 4})$ are still unknown. The molecular docking technique is used to predict their possible targets. On the basis of literature search, three bacterial proteins are choosed. The protein enzymes used are given in the following: an enzyme MurD ligase (PDB ID:
2X5O, 3UDI) and dihydropteroate synthase enzyme (DHPS; PDB ID: 3TYE). The docking score values of the synthesized compounds are given in Table-5. The compound $\mathbf{4 c}$ shows an excellent binding score -7.8 and -7.5 for an enzyme MurD (PDB ID: 3UDI and 2X5O). It clearly result that the electron withdrawing substitution has excellent bacterial inhibition. The

\begin{tabular}{|c|c|c|c|c|c|c|}
\hline \multicolumn{7}{|c|}{$\begin{array}{c}\text { TABLE-4 } \\
\text { ZONE OF INHIBITION VALUES OF COMPOUNDS } \mathbf{4 a - 4 c}\end{array}$} \\
\hline \multirow{3}{*}{ Compound } & \multicolumn{6}{|c|}{ Zone of inhibition (diameter) } \\
\hline & \multicolumn{3}{|c|}{ Staphylococcus aureus } & \multicolumn{3}{|c|}{ Escherichia coli } \\
\hline & $10 \mu \mathrm{g} / \mathrm{mL}$ & $5 \mu \mathrm{g} / \mathrm{mL}$ & $2.5 \mu \mathrm{g} / \mathrm{mL}$ & $10 \mu \mathrm{g} / \mathrm{mL}$ & $5 \mu \mathrm{g} / \mathrm{mL}$ & $2.5 \mu \mathrm{g} / \mathrm{mL}$ \\
\hline $4 a$ & 19 & 16 & 12 & 16 & 14 & 10 \\
\hline $4 \mathrm{~b}$ & 16 & 15 & 8 & 19 & 12 & 7 \\
\hline $4 c$ & 22 & 19 & 13 & 15 & 13 & 10 \\
\hline
\end{tabular}

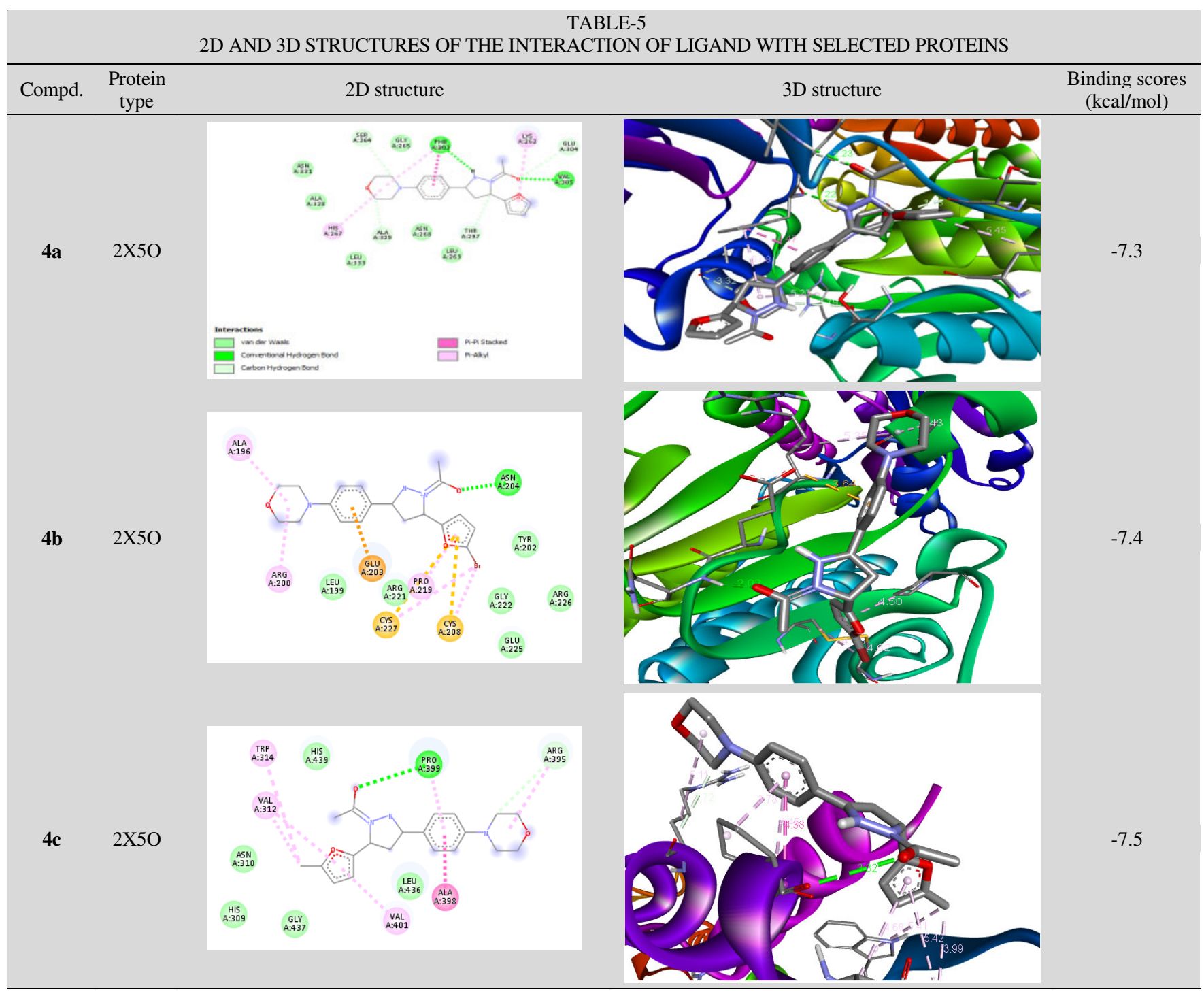




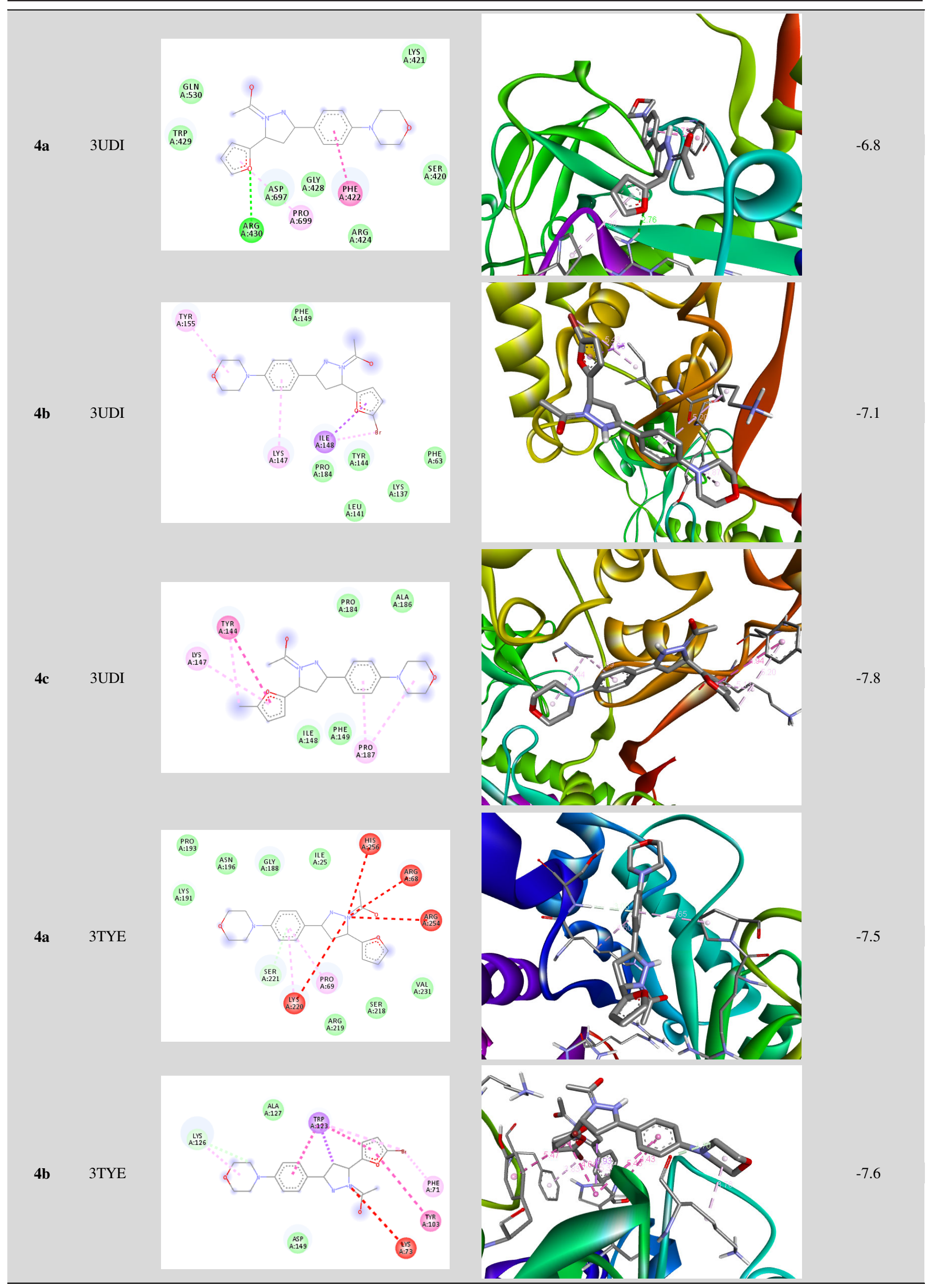




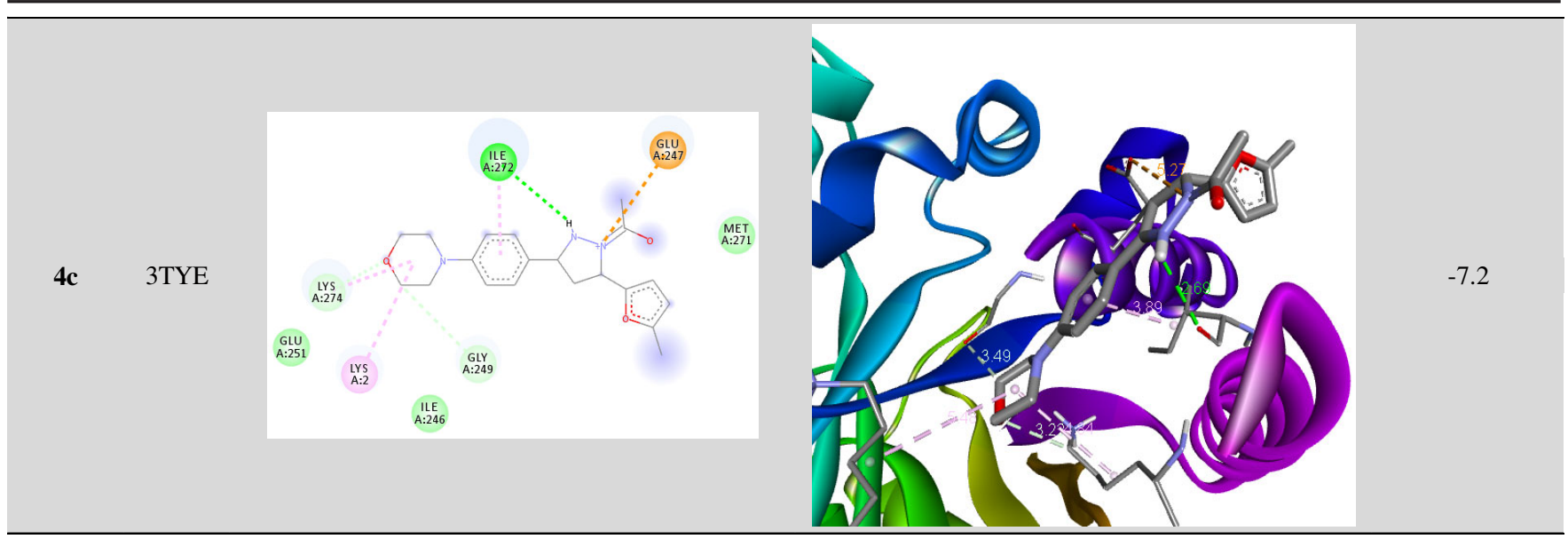

synthesized compounds $\mathbf{4 a - 4} \mathbf{c}$ with MurD enzyme (PDB ID: $2 \mathrm{X} 5 \mathrm{O}$ ) have the best binding values in the range of -7.5 to -7.3 . In the DHPS binding pockets the compound $\mathbf{4 b}$ shows a high binding score -7.6 (the $\mathbf{4 b}$ compound, the $\mathrm{CH}_{2}$ group in the morpholine moiety form carbon-hydrogen bond with LYS A:126 and the aromatic and heteroaromatic ring form a $\pi-\sigma$ bond which is form alkyl binding with PHE A:71). The binding scores and 2D, 3D binding structures of all the synthesized compounds among three bacterial proteins are given in Table-5.

Molecular docking studies show that the synthesized compounds could act as very good inhibitors for DHPS and MurD ligase. This study gives an idea for the designing more effective antibacterial agents in the future.

\section{Conclusion}

The target compounds are successfully synthesized via Scheme-I reaction (Michal addition). The chemical structure of the synthesized compounds are identified by IR, ${ }^{1} \mathrm{H}$ NMR and ${ }^{13} \mathrm{C}$ NMR spectral values. The antibacterial inhibition tests are screened. From that result, the electro-negativity substituted compound like Br shows an excellent inhibition against Grampositive strain (Staphylococcus aureus) and the electron donating substituent like $\mathrm{CH}_{3}$ shows the best inhibition zone against Gram-negative bacterial strain (Escheichia coli). Finally, the molecular docking studies help to predict the in silico screening of synthesized compounds with MurD enzyme and DHPS enzyme proteins. It can be concluded that the compounds $\mathbf{4 a - 4 c}$ inhibit cell wall synthesis of bacteria there by inhibiting the growth of the bacteria.

\section{REFERENCES}

1. V. Kumar, K. Kaur, G.K. Gupta and A.K. Sharma, Eur. J. Med. Chem., 69, 735 (2013); https://doi.org/10.1016/j.ejmech.2013.08.053.

2. A.M. Vijesh, A.M. Isloor, P. Shetty, S. Sundershan and H.K. Fun, Eur. J. Chem., 62, 410 (2013); https://doi.org/10.1016/j.ejmech.2012.12.057.

3. R. Aggarwal, V. Kumar and S.P. Singh, Indian J. Chem., 46B, 1332 (2007).

4. D.C. Malvar, R.T. Ferreira, R.A. de Castro, L.L. de Castro, A.C.C. Freitas, E.A. Costa, I.F. Florentino, J.C.M. Mafra, G.E.P. de Souza and F.A. Vanderlinde, Life Sci., 95, 81 (2014); https://doi.org/10.1016/j.lfs.2013.12.005.

5. E. Mosaddegh, M.R. Islami and Z. Shojaie, Arab. J. Chem., 10, S1200 (2017); https://doi.org/10.1016/j.arabjc.2013.02.016.

6. M. Suri, T. Jousseaume, J.J. Neumann and F. Glorius, Green Chem., 14, 2193 (2012);

https://doi.org/10.1039/c2gc35476d.
7. N. Shao, T. Chen, T. Zhang, H. Zhu, Q. Zheng and H. Zou, Tetrahedron, 70, 795 (2014);

https://doi.org/10.1016/j.tet.2013.12.046.

8. M.R. Ezhilarai and B. Prabha, Res. J. Chem. Sci., 5, 1 (2015).

9. R. Surendra Kumar, I.A. Arif, A. Ahamed and A. Idhayadhulla, Saudi J. Biol. Sci., 23, 614 (2016);

https://doi.org/10.1016/j.sjbs.2015.07.005.

10. K.T. Ashish, M. Anil, H.N. Verma and A. Mishra, Indian J. Chem., 45B, 489 (2006)

11. S. Ningaiah, U.K. Bhadraiah, S.D. Doddaramappa, S. Keshavamurthy and C. Javarasetty, Bioorg. Med. Chem., 24, 245 (2014); https://doi.org/10.1016/j.bmcl.2013.11.029.

12. S. Viveka, Dinesha, L.N. Madhu and G.K. Nagaraja, Monatsh. Chem., 146, 1547 (2015); https://doi.org/10.1007/s00706-015-1428-5.

13. A. Cetin and I. Bildirici, J. Saudi Chem. Soc., (2016); https://doi.org/10.1016/j.jscs.2016.05.008.

14. M. Shahar Yar, M.A. Bakht, A.A. Siddiqui, M.M. Abdullah and E. De Clercq, J. Enzyme Inhib. Med. Chem., 24, 876 (2009); https://doi.org/10.1080/14756360802447917.

15. M.D. Altintop, A. Ozdemir, S. Ilgin and O. Atli, Drug Des. Discov., 11, 833 (2014); https://doi.org/10.2174/1570180811666140226235350.

16. P.B. Miniyar, M.A. Barmade and A.A. Mahajan, J. Saudi Chem. Soc., 19, 655 (2015); https://doi.org/10.1016/j.jscs.2013.12.004.

17. D. Sriram, P. Yogeeswari, J.S. Basha, D.R. Radha and V. Nagaraja, Bioorg. Med. Chem. Lett., 13, 5774 (2006); https://doi.org/10.1016/j.bmc.2005.05.063.

18. M. Johnson, B. Younglove, L. Lee, R. Leblanc, H. Holt Jr., P. Hills, H. Mackay, T. Brown, S.L. Mooberry and M. Lee, Bioorg. Med. Chem. Lett., 17, 5897 (2007); https://doi.org/10.1016/j.bmcl.2007.07.105.

19. P.O. Patil and S.B. Bari, Asian J. Chem., 25, 3588 (2013); https://doi.org/10.14233/ajchem.2013.13662.

20. M.R. Ezhilarasi, B. Prabha and M. Kulandhaivel, Eur. J. Pharm. Med. Res., 2, 355 (2015).

21. I. Loewe, W.R. Balzer and S. Gerstung, Chem. Abstr., 128, 16281 (1997).

22. I. Çelik, N. Kaniskan and S. Kökten, Tetrahedron, 65, 328 (2009); https://doi.org/10.1016/j.tet.2008.10.047.

23. S. Yadav, P. Rai, M. Srivastava, J. Singh, K.P. Tiwari and J. Singh, Tetrahedron Lett., 56, 5831 (2015). https://doi.org/10.1016/j.tetlet.2015.07.039.

24. M.R. Ezhilarasi, B. Prabha and T. Santhi, Chem. Sci. Rev. Lett., 4, 1216 (2015).

25. V. Kanagarajan, M.R. Ezhilarasi and M. Gopalakrishnan, Spectrochim. Acta A Mol. Biomol. Spectrosc., 78, 635 (2011); https://doi.org/10.1016/j.saa.2010.11.038.

26. V. Kanagarajan, M.R. Ezhilarasi and M. Gopalakrishnan, Org. Med. Chem. Lett., 1, 8 (2011); https://doi.org/10.1186/2191-2858-1-8.

27. M. Rani and Y. Mohamad, J. Saudi Chem. Soc., 18, 411 (2014); https://doi.org/10.1016/j.jscs.2011.09.002.

28. C.A. Lipinski, F. Lombardo, B.W. Dominy and P.J. Feeney, Adv. Drug Deliv. Rev., 46, 3 (2001); https://doi.org/10.1016/S0169-409X(00)00129-0.

29. R. Sri Dharani, R. Ranjitha, R. Sripathi, K.S. Ali Muhammed and S. Ravi, Asian J. Pharm. Clin. Res., 9, 121 (2016); https://doi.org/10.22159/ajpcr.2016.v9i5.12693. 